\title{
Rusty soil - gleba rdzawa - Soil of the Year 2021 in Poland. Concepts of genesis, classification and regularities of geographical distribution
}

\author{
Michał Jankowski*, Renata Bednarek \\ Faculty of Earth Sciences and Spatial Management, Nicolaus Copernicus University in Toruń, ul. Lwowska 1, 87-100 Toruń, Poland \\ * PhD, Habil. Michał Jankowski, professor of the Nicolaus Copernicus University in Toruń, ORCID iD: https://orcid.org/0000-0003-4220-5883, mijank@ \\ umk.pl, phone: +48 56 611-25-57
}

Received: 01.12.2021

Accepted: 06.01.2022

Associated editor: C. Kabała

\section{Keywords}

Rusty soil

Brunic Arenosol

Soil of the year

Soil genesis

Soil classification

Soil geography

\begin{abstract}
Gleba rdzawa (Pol.) - the rusty soil is a soil type distinguished in Polish classification system that has been elected as the soil of the year 2021 in Poland. Rusty soils are mainly coarse textured soils, developed from sandy deposits of various origin (glaciofluvial, fluvial, less often aeolian and of weathering) with A-Bv-C horizon sequence. Pale orange enrichment horizon Bv-siderik is a diagnostic one of these soils. The agricultural quality of rusty soils is low, but they constitute valuable habitats of natural and managed forests, on the territory of Poland occupying over $50 \%$ of all the forest area. The article discusses the general concepts of the genesis of rusty soils in the following aspects: (1) 'rustyfication' - formation of Fe-Al coatings on sand grains in the Bv horizon, (2) 'dry pedoclimate' - as an assumed factor responsible for the lack of Fe-Al-oxides mobility, (3) coniferous forest vs deciduous forest vegetation as a soil-forming factor, (4) Pleistocene vs Holocene age and the possible role of periglacial conditions. In Polish classification system rusty soils are currently located close to brown soils (Cambisols), however, in the past they were located in one taxonomic unit with podzolic soils. In international classifications such soils are not distinguished separately and belong to Brunic Arenosols/Psamments. The largest areas of rusty soils in Poland are located in lowlands and uplands, mainly on sandy surfaces of outwash plains, and terraces of ice-marginal streamways and valleys.
\end{abstract}

\section{Introduction}

Gleba rdzawa (Pol.) - the rusty soil - is the type of soil that has been elected as the soil of the year 2021 by the Commission for the Soil Genesis, Classification and Cartography of the Soil Science Society of Poland.

Rusty soils are well developed sandy soils whose main diagnostic feature is the presence of a characteristic pale orange (rusty) coloured, relatively deep enrichment horizon (Bv) that in Polish soil science is named siderik (SGP 6, 2019). Rusty soils are a common element of the soil cover in Poland and also the whole area of Central European Lowlands. That region is located inside the so-called 'Central European sand belt' (Zeeberg, 1998), where sandy deposits of various origin (glaciofluvial, fluvial, aeolian), forming parent rocks especially suitable of rusty soils development, are especially widespread.

Public attention and colloquial perception of soils and their role in the environment and human economy is mainly focused on agricultural issues. The intention of the Commission for the Soil Genesis, Classification and Cartography of the SSSP was, however, to emphasize the fact that also less fertile sandy soils, not as much useful for agriculture, are an important element of environment, shaping valuable habitats of natural or seminatural forest ecosystems, as well as managed woodlands. For this reason, these less fertile, sandy soils are a basis for forestry and wood industry - an important branch of the Polish economy (https://www.torun.lasy.gov.pl/pgl-lasy-panstwowe). The rusty soils, on the teritory of Poland are the most important forest soils, occupying over $50 \%$ of all the forest area of the country (https:// www.bdl.lasy.gov.pl/portal/mapy; Rutkowski et al., 2021).

Poland is one of the pioneer countries, where studying individual characteristics of rusty soils has several decades of tradition and where these soils were identified as a distinct soil type in the national classification (SGP 3, 1974). Studies on rusty soils in Poland started in the mid-twentieth century. Probably for the first time the term "gleby rdzawe” was used by Jan Tomaszewski in the 1950s (Białousz et al., 2021), although in Germany analogous soils were described as 'Rostfarbene Waldböden' by Stremme, even in late 1930s (Stremme, 1939). Since the 1960s rusty soils commonly occur in Polish literature. During the last ca. seven decades numerous studies on these soils were realised by the researchers from various Polish academic centers. The Authors' attention in the present paper was focused on the following aspects: 
1. Genesis and age of rusty soils - the subject of two monographic books entirely dedicated to rusty soils (Bednarek, 1991; Janowska, 2001) and several other publications (e.g. Kowalkowski 1977a, Manikowska, 1985; Kowalkowski et al., 1985, 1986; Szafranek, 1989, 1992; Konecka-Betley, 1991; Manikowska and Bednarek, 1994; Konecka-Betley and Janowska, 1996, 2005; Jankowski, 2003, 2019; Czubaszek, 2006; Świtoniak, 2021).

2. Regularities of geographical distribution of rusty soils (Uggla and Roszko, 1974; Kuźnicki et al., 1978; Białousz, 1978; Prusinkiewicz, 1969; Kowalkowski and Borzyszkowski, 1974; Kowalkowski et al., 1981; Konecka-Betley et al., 2002; Czępińska-Kamińska, 1986; Prusinkiewicz et al., 1980; Marzec and Kabała, 2008; Degórski et al., 2013; Jonczak and Sztabkowski, 2021).

3. Characterization of rusty soils physical, chemical, physicochemical and biological properties and their transformation due to land use (Kuźnicki and Skłodowski, 1974; Kowalkowski, 1977b; Kowalkowski and Szczęsny, 1977, 1978; Kowalkowski et al., 1977; Ostrowska, 1977; Chudecki and Błaszczyk, 1980; Skłodowski, 1986; Skłodowski and Maciejewska, 1986; Maciejewska, 1993; Pokojska et al., 1995, 1999; Malczyk, 1998; Nowiński, 1998, 1999; Szafranek, 1998, 2000; Szafranek and Skłodowski, 1998; Magnuski et al., 2001; Dziadowiec et al., 2002; Świercz, 2005; Becher and Kalembasa, 2006, 2008; Kalembasa and Becher, 2006; Wawrzyniak-Gramacka and Drab, 2007a, 2007b; Smal and Olszewska, 2008; Bryk, 2009; Martyn and Niemczuk, 2009, 2011; Wójcikowska-Kapusta and Niemczuk, 2010; Kobierski et al., 2011; Kondratowicz-Maciejewska et al., 2012; Błońska et al., 2013; Jonczak, 2014; Lemanowicz, 2015; Jonczak et al., 2019; Kabała et al., 2021; Lasota et al., 2021).

4. Management of rusty soils (Niedźwiecki, 1984; Bednarek and Michalska, 1998; Szafranek and Skłodowski, 2004; Skłodowski et al., 2004; Smreczak et al., 2021) with special focus at their ecological interpretation and evaluation of value for forestry (Biały, 1997, 1999; Brożek et al., 2008; Jankowski, 2003, 2014; Chudecka and Tomaszewicz, 2014; Jamroz et al., 2014; Chojnicki, 2020; Chojnicki et al. 2021 a, b; Sewerniak and Jankowski, 2021; Smólczyński et al., 2021).

In the journal Soil Science Annual (SSA) (in 1950-2011 journal's name was Roczniki Gleboznawcze), including the current issue, the term 'gleby rdzawe' was used ca. 40 times in article titles, keywords and abstracts (Table 1). In papers indexed in the Polish scientific datebase 'Biblioteka Nauki' (https://yadda.icm. edu.pl) the keyword 'gleby rdzawe' occurs 56 times. Of course, various aspects of the rusty soils research, in combination with other soils, were an integral element of many more works. In the google scholar database, the term 'gleby rdzawe' appears in around 2,300 items (https://scholar.google.com). For the purposes of this study, 100 publications on rusty soils were collected. In these numbers, most works were dedicated to soil properties and their transformations, some to soil genesis, age and regularities of geographical distribution and only few to the general management issues.

Until these days, numerous controversies, especially around the rusty soils' origin are not unequivocally resolved and generate academic discussions about the classifiation of these soils, their ecological potential and principles of sustainable management, especially in forestry.

The aim of this paper is to present main concepts of the rusty soils' genesis, time of formation, classification, general regularities of geographical distribution and management that have been formulated by Polish soil scientists in the second half of the $20^{\text {th }}$ century and the first two decades of the $21^{\text {st }}$ century.

\section{Concepts of rusty soils genesis}

\subsection{General mechanisms of rusty soils formation}

In Polish literature development of rusty soils is considered as a separate soil-forming typological process. In literal translation from Polish this process can be named the 'rusting' or applying the rule of adapting non-English, international names of soil-forming processes the 'rustyfication' or the 'rustyzation' (Pol. proces rdzawienia; SGP 4, 1989; Bednarek and Skiba, 2015). The main mechanism of this process is defined as the formation of stable rusty coloured coatings on grains of sand fraction (SGP 3 , 1974). The coatings are built from iron and aluminum oxides with some admixture of organic matter (mostly around $0.5 \%$ of organic carbon - OC content). Weathering of primary iron-containing aluminosilicate minerals is the source of $\mathrm{Fe}$ - $\mathrm{Al}$-oxides and organic (humic) acids originated from the organic matter decomposition is the source of OC. Oxides and organo-mineral complexes in classical literature are interpreted to be accumulated due to in situ (understood as non-illuvial) transformation, similarly to the kambik horizon formation, however with no (or no significant) clay minerals contribution (SGP 3, PTG 1974; Bednarek and Skiba, 2015). From the other side, they are interpreted as immobile forms, that effects in lack of eluvial (Es - albik) and illuvial (Bhs - spodik) horizons, which develop, when podzolization is an active soil-forming process. Immobility of Fe-Al oxides in the diagnostic enrichment horizons Bv - siderik is explained by limiting factors: (1) relative richness of parent material in iron and aluminum compounds (higher than in Pod-

\section{Table 1}

The occurrence of the term 'gleby rdzawe' in the titles, keywords and abstracts of articles published in the Soil Science Annual (SSA) journal 1950 (1974)-2021, indexed in the 'Biblioteka Nauki' (BN) database and collected for the purposes of this work

\begin{tabular}{llll}
\hline Topics: & $\begin{array}{l}\text { Genesis, age, } \\
\text { geographical distribution }\end{array}$ & Properties & Management \\
\hline SSA & 8 & 21 & 11 \\
BN & 7 & 45 & 4 \\
This work & 42 & 44 & 14 \\
\hline
\end{tabular}


zols), (2) insufficient production of fulvic acids during organic matter decomposition (lower than in Podzols), (3) the proportion of $\mathrm{OC} / \mathrm{Fe}+\mathrm{Al}$ to low to enable eluviation.

This theory, however, does not explain why in most cases $\mathrm{Bv}$ - siderik horizons and also A humic horizons of proper rusty soils contain more $\mathrm{Fe}$ and $\mathrm{Al}$ than the parent rock $\mathrm{C}$, visible not only for their pedogenic (dithionite-bicarbonate-citrate extractable $-\mathrm{Fe}_{\mathrm{d}}$ ) forms but also for total contents. This fact suggests, that there is an accumulation of $\mathrm{Fe}$ and $\mathrm{Al}$, starting from the topsoil and occuring throughout the whole solum of a rusty soil and thus, 'rustyfication' may not (or not only) be a really non-illuvial process, but at least some part of these compounds has to originate from an external source. Concerning the lack of any supply of ingredients from outside the pedon, in our opinion, the only explanation of that enrichment is bioaccumulation - the redistribution of compounds through the biological activity. It is obvious, that the original vegetation that participated in the development of rusty soils, had to derive components using root systems from the entire volume of soil and also reaching the parent rock. These components in condensed form are returned along with plant remains back to the soil surface (litter) and underground (roots, etc.), accumulating with time and forming A and Bv horizons. Verification of this concept needs, however, additional research.

\subsection{The concept of 'dry pedoclimate'}

In several works analysing distribution of soils in inland dune areas of Poland distribution of rusty soils was associated with summit parts of dune hills. Such situation was reported e.g. from dunes in the valleys of the Biebrza and Narew rivers (Banaszuk, 1979; Czubaszek and Banaszuk, 2004) and in the Warsaw Basin (the Kampinos forest; Czępińska-Kamińska, 1986; Janowska, 2001; Konecka-Betley et al., 2002). In the most extreme situation, not only the summits but the entire dune forms and even large dune fields were marked as dominated by rusty soils on soil-habitat maps edited for areas administrated by the State Forests, e.g. in the Torun Basin (Operat, 1999). Such landscape position of these soils was interpreted as an effect of a specific climate conditions (pedoclimate) supposed to form inside the soils occupying the summits. As the most elevated and exposed places they are expected to be a subject of drying up to a state that enables downward water movement in the soil profile and development of podzolization, normally dominating on surrounding dune slopes.

Such a concept, however, raises several doubts. Firstly, sizes of inland dunes in Poland (mainly they rich the height of 10-20 meters, maximum $45 \mathrm{~m}$, and a slope lenght of several dozen meteres) seem to be insufficient to generate climatic variability decisive for differentiating directions of soil-forming processes. Although, topoclimatic variability of dune slopes of various exposition (northern and southern) is noticeable (Sewerniak and Jankowski, 2017; Sewerniak and Puchałka, 2020), it may only modify the intensity and pace of soil-forming processes but not their general direction (Rutkowska, 2019). With uniform lithology, vegetation and automorphic water regime even on much more extensive landforms characterised with more significant topoclimate variability, typical of mountainous areas (vertical bioclimatical zonation), topographical differentation of soil forming processes is not always as obvious (e.g. Sommer et al., 2001).

Secondly, morphology and chemical properties of the soils occupying top parts of dune hills are significantly different from rusty soils developed from outwash and terrace deposits. In most cases these soils show features much more typical of weakly advanced podzolization (presence of bleached eluvial zone and thin gradually fading illuvial Bs or BC horizon) than 'rustyfication' (deep homogenous Bv horizon) and thus, they should be classified as weakly developed podzolic soils or podzolized arenosols rather than as rusty soils. It is necessary to underline, that some researchers noticed the difference between soils occupying the tops of dunes and the rest of the rusty soils (Prusinkiewicz, 1969; Białousz, 1978; Kuźnicki et al., 1978), calling the first of them 'cryptopodzolic' soils (Prusinkiewicz, 1969). Weak degree of their development - interpreted formerly as dominance of 'rustyfication' - is rather a result of the high susceptibility of soils at dune tops to the degradation processes (erosion and deflation), in the case of any destruction of the vegetation cover. Such interpretation was formulated on the basis of studies carried out on dunes in the Torun Basin (Jankowski, 2003, 2019; Sewerniak and Jankowski, 2021). In case of the Biebrza and Narew River valleys podzolization as the process forming soils on dunes was confirmed by works of Czubaszek (2006). For dune soils of the Warsaw Basin the same conclusion was made as a result of the discussion during the field session of the 27 Congress of the Soil Science Society of Poland in 2007.

Thirdly, in numerous profiles of rusty soils illuvial bands (lamellae) were reported (e.g. Prusinkiewicz et al., 1998; Brożek and Zwydak, 2003; Jankowski, 2018; Gus-Stolarczyk et al., 2021) seeming to contradict the theory of the total immobility of iron and aluminum compounds related to the dry pedoclimate. Actually, it is widely accepted that pedogenic lamellae form according to the illuviation of clay fraction, and also Fe-Al-coompounds (Prusinkiewicz et al., 1998; Rawling, 2000; Gus-Stolarczyk et al., 2021) and their presence indicates that leaching of $\mathrm{Fe}$ and $\mathrm{Al}$ by water seeping downward into the soil profile takes place in rusty soils, as well as in podzolic and clay-illuvial (lessive) soils often occurring in close neighborhood. The specifity of rusty soils relates to the fact, that possible loss of components which could occur in their top horizons due to leaching may be compensated by bioaccumulation, as it is sugested in the chapter 2.1 .

\subsection{Vegetation as a soil-forming factor}

Most of rusty soils in Poland are actually overgrown with managed pine woodlands (Pinus sylvestris L.). For decades the opinion on the compliance of such vegetation with rusty soils' ecological potential dominated the scientific views and principles of forest management (SGP 3, 1974; Prusinkiewicz et al., 1980; SGP 4, 1989; Brożek and Zwydak, 2003). However, in profiles of rusty soils overgrown with pines morphological and chemical effects of podzolization (bleaching of quartz grains or even formation of thin layer of albik material as well as quantitative evidence for the translocation of $\mathrm{Fe}$ and $\mathrm{Al}$ ) are regularly 
present in the top, over the Bv - siderik horizon. The intesity of podzolization seems to be related to the age of pine stands and the mineralogical richness of parent material (Jankowski, 2014). From the other side, in numerous areas managed as pine wodlands spontanous encroachment of deciduous tree species, such as oak (Quercus sp.), hornbeam (Carpinus betulus L.), beech (Fagus sylvatica L.) and maple (Acer sp.) on rusty soils is observed with time. Thus, there appears the suggestion, that such trees, more demanding but also more competitive than pine, may succesfully grow on these soils and perhaps they constitute a potential vegetation participating in rusty soils formation (Biały, 1997, 1999; Jankowski, 2014, 2019; Andrzejczyk and Sewerniak, 2016; Sewerniak and Jankowski, 2021). In the Brodnica Lakeland the phenomena of obliteration of former podzolization effects and regeneration of rusty soils under encroaching deciduous trees was documented, seeming to confirm such concept (Jankowski, 2014). Thus, coniferous woodlands widely planted on rusty soils in Poland should be interpreted as an anthropogenic factor causing their transformation - replacing primary 'rustyfication' with secondary podzolization. Considering ecological potential such vegetation should be perceived as disconcordant with rusty soils and the described phenomena even as a habitat degradation process.

It is worthy to notice, that first suggestions of higher ecological potential of rusty soils in comparizon with other automorphous sandy soils (podzolic soils, arenosols, 'cryptopodzolic' soils) appeared decades ago (Prusinkiewicz, 1969; Białousz, 1978; Kuźnicki et al., 1978).

\subsection{The role of periglacial conditions and age: Pleistocene vs Holocene}

Until today, a number of controversies have arisen regarding the age and climatic conditions under which rusty soils may form. For decades, the theory that rusty soils and their characteristic enrichment horizons Bv-siderik are actually of a relict nature and formed in the periglacial climate of the late Pleistocene was very popular (Kowalkowski, 1977a, 1988; Degórski et. al., 2013). The concept, adapted from German literature (Jäger and Kopp, 1969) was accepted by numerous Polish authors and even established in some editions of the Polish soil classification systems as the only possible explanation of the genesis of rusty soils (SGP 3, 1974; SGP 4, 1989; Klasyfikacja gleb leśnych Polski, 2000). Mainly three arguments supporting this idea are exposed by its proponents: (1) presence of the layer enriched with clay and/or gravel fraction sometimes occuring in the bottom of the siderikBv horizon. This layer quite often has a garland shape, and can also emphasize the shapes of cryogenic structures (pseudomorphoses of frost wedges). It is widely interpreted as a relict of the Pleistocene permafrost and active layer border (Kowalkowski et al., 1986). In the SGP 4 it was called the 'cryoilluvial horizon' and marked 'Bk' (SGP 4, 1989), (2) traces of quartz grain shape and surface transformation in the periglacial (e.g. sharp edges, fracture planes, various angular outlines, conchoidal fractures; Woronko and Pisarska-Jamroży, 2016) and aeolian (rounded, mat; Mycielska-Dowgiałło and Woronko, 2004) environments recorded in SEM (scanning electron microscope) observations
(Kowalkowski and Mycielska-Dowgiałło, 1980; Kowalkowski et al., 1986; Bednarek, 1991; Janowska, 2001), (3) presence of silt fraction interpreted as an effect of sand grains physical weathering in multiple freezing-thawing cycles (Kowalkowski et al., 1985, 1986).

Although, activity of periglacial processes at the end of the Pleistecene on the territory of Poland is obvious; however, all the features above mentioned relate to parent rock formation in geomorphologically active environment (sedimentation, reworking by redeposition and cryoturbations) rather, than to effects of soil-forming processes sensu stricto. Moreover, none of these features are present in all rusty soil profiles, but only in some of them, as well as in part of clay-illuvial soils, podzolic soils, chernozems, etc. It seems to be more credible that the relict features acquired by the parent rock in the periglacial environment could have conditioned the depth of later (Holocene) pedogenesis and in some cases these periglacial features were just emphasized by subsequent soil-forming processes.

From the other side, no datings unequivocally indicative of the Pleistocene age of rusty soils/siderik-Bv horizons were presented in any publication, while numerous radiocarbon and archaeological datings show, that they could develop in various phases of the Holocene. According to Manikowska and Bednarek (1994) and Konecka-Betley and Janowska (2005) rusty soils were typical soils of central Poland in early Holocene (Preboreal period). Two generations of rusty soils ocurring in vertical chronosequences were documented from the Tuchola forests - developed before and after ca. 2400 BP (Bednarek, 1991), in the Torun Basin - formed during the Eo-mesoholocene and Neoholocene (Bednarek, 2000; Jankowski, 2002, 2003, 2019) and in the Kuiavia region - related to post Neolithic (Neoholocene) period (Jankowski, 2018).

Considering these facts, accepting the Pleistocene-periglacial concept of rusty soils genesis a priori seems to be unauthorized, however, such interpretation has followers until today (Hirsch et al., 2015).

\section{Classification position of rusty soils}

For the first time in Poland rusty soils were officialy distinguished as a separate type, in the third edition of the Classification system of Polish Soils (SGP 3, 1974). In earlier editions they were considered as a sandy variant of brown soils (SGP 1, 1956; SGP 2, 1959). In this genetic, qualitative classification (SGP 3, 1974), rusty soils were included in the class of 'podsol-earth' soils, next to 'podsolic soils' and 'podsols'. The basis for combining these three soil types into one group was the assumption of 'similar biological, physical and chemical properties' and 'a similar system of biological and abiotic factors of the geographical environment'. This concept, mainly related to sandy texture of these soils evidences the prevailing opinion of their low ecological value and connection with coniferous vegetation. Two subtypes of rusty soils were distinguished at that time: 'proper rusty soils' and 'podsolized rusty soils', dividing soils without or with visible evidence of podzolization. The rusty enrichment horizon, characteristic of these soils, was marked with the symbol 'B'. 
In the fourth edition of the classification system - the Systematics of Polish Soils (SGP 4, 1989) rusty soils were separated in the division of 'autogenic soils' and order of 'podzol soils' together with podzolic soils and podzols. The above mentioned classification, for the first time in Poland, has introduced diagnostic horizons whose definitions were based not only on qualitative criteria, but primarily on quantitative criteria. The sideric horizon (Greek: sideros - iron) was considered to be the diagnostic horizon for rusty soils. However, the symbolism adopted to mark this horizon largely reflected the views on the genesis of rusty soils prevailing in Polish soil science at that time. The symbol 'Bv' was adopted for rusty periglacial soils, 'Bvre' for rusty relict soils and 'Br' for cultivated rusty soils. In the rusty soil type, three subtypes were distinguished: 'proper rusty soils', 'brownish rusty soils' (new in comparison to the previous edition) and 'podzolized rusty soils' (equivalent to 'podsolized rusty soils' from the SGP 3,1974).

With next editions of SGP gradual change in perception of rusty soils ecological valuae is visible.

In the fifth edition of SGP (2011) rusty soils were distinguished in a rank of individual order of 'rusty soils', separete from the order of 'podzol soils'. The diagnostic horizon for these soils sideric, had the symbol 'Bv'. In the order of rusty soils, in addition to the type of rusty soils, a new type was distinguished, so far not included in the Polish soil taxonomies - ochre soils - including sandy red-coloured pedons (Rubic Arenosols; Jankowski, 2013). Within the rusty soil type, three subtypes were distinguished: typical rusty soils, podzolic rusty soils and gleyic rusty soils. It should be emphasized that in the definition of rusty soils and in the symbolism of the sideric - Bv horizon, the information about periglacial conditions of their formation has been rightly abandoned.

The newest proposal of the Commission for the Soil Genesis, Classification and Cartography of the Soil Science Society of Poland was edited in 2019 (SGP 6, 2019, Kabała et al., 2019). In this version, contrary to the previous one, rusty soils were not distinguished in the rank of a separate order, but included in the order of 'brown earths' (Cambisol-related soils) together with more soil types: brown soils, brown rendzinas, brown alluvial soils and ochrous soils. Such an assumption underlines not only morphological similarity with Cambisols (A-B-C horizon sequence), but also their at least mesotrophic character as well as ecological and genetic connection with mixed or even deciduous forests.

The siderik - Bv horizon diagnostic for rusty soils was defined mainly on the basis of quantitative criteria. Within the type of rusty soils, more subtypes were distinguished than in the 5th edition of the classification (SGP 5, 2011), i.e. typical rusty soils, brown-rusty soils, podzolic rusty soils, humic rusty soils and gleyic rusty soils.

In addition to the soil systematics discussed above, the Classification of Forest Soils has existed in Poland since 2000 (Klasyfikacja gleb leśnych Polski, 2000), which is used in habitat evaluation for forest management. This classification, developed by the Forest Soil Classification Team of the Polish Soil Science Society, refers to the former, edition of the Forest Soil Classification (Klasyfikacja gleb leśnych, 1973) and the 4th edition of the Systematics of Polish Soils (SGP 4,1989). Rusty soils in this classifica- tion were distinguished in the rank of the basic taxonomic unit, i.e. type. The diagnostic horizon is the sideric (Bv), characterized by a specific set of quantitative criteria. The definition of rusty soils emphasizes their genesis related only to periglacial conditions. In this classification, three sub-types of rusty soils were distinguished: 'proper rusty soils', 'rusty brown soils' and 'rusty podzol soils'.

The latest editions of classifications mentioned above (Klasyfikacja gleb leśnych Polski, 2000; SGP 6, 2019) extend the definition of rusty soils to pedons with finer grain-size distribution, providing for the possibility of including soils with the texture of loamy sand (SGP 6, 2019), silt and even sandy loam (Klasyfikacja gleb leśnych Polski, 2000) in this type. So far, however, the documentation of such soils in the scientific literature is very modest and does not allow for a broader discussion on them.

It is worthy to underline, that in international classification systems (Soil Survey Staff, 2014; IUSS Working Group WRB, 2015) analogues of the rusty soils are not distinguished as separate units at high classification level. Using WRB soil classification (IUSS Working Group WRB, 2015) such soils may be classified as Dystric Brunic Arenosols. According to Soil Taxonomy (Soil Survey Staff, 2014) they fit to the unit of Typic Udipsamments. The above names seem to be inappropriate as they suggest a poor level of profile development and group rusty soils in one unit with typical A-C arenosols, despite their genetic, ecological and economical individuality and also reletively high stage of development.

\section{Regularities of geographical distribution of rusty soils in Poland}

According to various estimations of the soil mantle of Poland rusty soils occupy about 14-15\% of the country's territory (Bednarek and Prusinkiewicz, 1980; Prusinkiewicz et al., 1980; Uziak and Klimowicz, 2002; Sykuła et al., 2019). However, this percentage seems to be not exact. From one side, taking into account detail cartographical analysis of Polish forest habitats (https://www.bdl.lasy.gov.pl/portal/; Rutkowski et al., 2021), where rusty soils cover about $50 \%$ and the information that afforested area of Poland is $30 \%$ one can notice that only forest rusty soils make up these $15 \%$. Meanwhile, about $1 / 3$ of all rusty soils may be in agricultural use (Prusinkiewicz et al., 1980). Thus, this figure seems to be underestimated and it should be seen at around $22,5 \%$ of the whole teritory of Poland. From the other side, however, many soils classified on soil-habitat maps of forest areas as 'rusty podzol soils', in fact are weakly developed or degraded podzolic soils or podzolized arenosols, as it was shown in several works (Jankowski, 2003, 2019; Czubaszek, 2006; Sewerniak and Jankowski, 2021).

Distribution of rusty soils is related mainly to coarse-grain (sandy and gravely) deposits of various origin. Mainly, there are sandy materials extensively sedimented according to the deglaciation of scandinavian ice-sheets and melt-waters outflow during the Pleistocene and subsequently redistributed by fluvial, slope and aeolian processes during the Late Glacial and the Holocene. Rusty soils cover extensive areas in lowland and upland part of 
Poland, on glaciofluvial and fluvial terrace systems of outwash plains, ice-marginal streamways and valleys. In such areas, they can form extensive homogeneous mantles or appear in mosaics and catenary systems with other sandy soils: podzolic, semimurshic and ochre soils (Podzols, Umbric Gleysols/Gleyic Arenosols, Rubic Arenosols). Rusty soils may occur also in washed out parts of ablational moraines, adjacent to clay-illuvial soils (Luvisols, Retisols). They appear also on smaller glaciofluvial and glaciolacustrine landforms such as kames and eskers. In aeolian sands rusty soils are rare and they occupy rather thin aeolian mantles overlying richer deposits and peripheries of dune fields (Jankowski, 2003, 2019).

Occurence of rusty soils in mountainous areas is ambiguous (Kowalkowski and Degórski, 2005). They were found in the Sudetes, as formed from sandy-textured products of the Karkonosze granites weathering (Marzec and Kabała, 2008). From the Carpathians they have not been reported until now (Skiba, 1995; Skiba and Drewnik, 2003), although, theoretically formation of rusty soils should be a possible process in wethering sandstones of the Beskides, especially corse-grained ones. In the Holy-Cross Mountains rusty soils were described as typical of weathered quartzites, sandstones of various age and periglacial slope mantles (Szafranek, 1989, 1990, 1992; Kowalkowski, 1994).

\section{Management of rusty soils in Poland}

Rusty soils are mainly managed as forest soils, afforested with stands of diverse tree-species composition - from fresh deciduous oak-hornbeam and oak forests, through mixed forests and mixed coniferous forests to homogenous pine monocultures (Brożek and Zwydak, 2003; Brożek et al., 2008, Lasota et al., 2011 a, b, c; Zwydak et al., 2011). However, it is rather unlikely, that such wide range of vegetation composition may reflect natural diversity. In the light of newer data it seems to be an effect of forest management and does not express their real habitat value (Biały, 1997, 1999; Jankowski, 2003, 2014, 2019; Sewerniak and Jankowski, 2021). The ranges of rusty soils overgrown with deciduous beech, oak-hornbeam and oak forests have been documented in several protected areas of Poland, despite their relatively low SIG (Soil Trophic Index) values (Lasota et al., $2011 \mathrm{a}, \mathrm{b}$ ).

Quality of rusty soils for agriculture is rather low (Prusinkiewicz et al., 1980; Skłodowski et al., 2004). Main disadvantages are related to sandy texture and may be listed as follows:

- low water storage that makes rusty soils easily drying out in periods of limited precipitation,

- low content of nutrients in soil mineral phase,

- high susceptibility of organic matter to mineralization, due to low content of clay minerals and lack of stable organomineral complexes,

- acid reaction, low cation exchange capacity and low base saturation.

Despite these disadvantages, it is estimated that up to $1 / 3$ of all rusty soils can still be used for agricultural purposes (Prusinkiewicz et al., 1980). This applies mainly to small patches of these soils located insularly among more fertile soils and in con- tact zones of sandy areas with areas composed of fine-grained sediments (for example outwash plains and moraine uplands), however, in regions, where more fertile soils are limited, rusty soils may constitute significant part of arable lands (e.g. parts of Mazovia, Podlasie, Łódź Province).

In Polish soils bonitation classification developed strictly for economical purposes rusty soils are included in the worst classes V and VI and only pedons with loamy sandy texture in humic horizons and pedons containing loamy/silty interlayers may be classified as IVb (Smreczak et al., 2021). The agricultural usefulness of these soils is limited to soil-agricultural complexes 6 (weak rye complex) and 7 (the weakest rye complex). Only in some cases, rusty soils built from sands shalowly underlaid with finer materials (loamy/silty/clayey) or having loamy-sandy texture in the topsoil may be put in the complex 5 (rye good complex).

\section{Summary}

Despite the fact that rusty soils are an important element of the soil cover of Poland, especially its forest areas, and despite long history of scientific research, until now many aspects of the genesis, utility value and ecological potential of these soils are controversial. Over decades of studies several theories of rusty soils formation have been developed, which are also reflected in the evolution of their classification. Due to numerous doubts and unresolved questions, these concepts, however, cannot be considered unambiguously proven.

Summarizing the facts presented in this paper, at the actual stage of knowledge, the genesis of rusty soils should be understood as the process of accumulation of components (including iron and aluminum) in the solum as a result of (1) intensive weathering of primary minerals, usually occurring in coarse-grained (sandy) rocks and (2) biological cycling induced by deciduous forest vegetation. Although, in such conditions, in the moderate relatively humid climate of Central Europe, leaching of components must take place, the specific redistribution of components by deciduous forest vegetation compensates any losses in the topsoil.

In Polish pedology the process of the rusty soils formation is called 'proces rdzawienia' (in literal translation 'rusting', 'rustyfication' or 'rustyzation'). Its main effect is the formation of rusty-coloured coatings covering larger mineral grains in the diagnostic enrichment horizon of Bv-siderik and in the overlying humus horizon A. Unlike the Bw-kambik horizons of brown soils (Cambisols), clay minearals do not play a major role in the siderik horizons. The latest editions of Polish soil classifications extend the definition of rusty soils to pedons with finer texture (loamy sand and even finer). However, documentation of such soils in the scientific literature is very modest and requires further completion.

Despite the fact that rusty soils (like mineral soils of other types in Poland) are often developed in the Pleistocene deposits processed in periglacial conditions, the course of the soil-forming process leading to their formation should be associated with various phases of the Holocene, up to the present day. 
The exact share of rusty soils in the soil cover of Poland is not precisely established. The existing estimates show that it is between 15 and $22.5 \%$.

\section{Acknowledgements}

We thank very much professor Cezary Kabała and two anonymous Reviewers for relevant essential and editorial comments on the text of this article.

\section{References}

Andrzejczyk, T., Sewerniak, P., 2016. Gleby i siedliska drzewostanów nasiennych dębu szypułkowego (Quercus robur) i dębu bezszypułkowego (Q. petraea) w Polsce. Sylwan 160(8), 674-683.

Banaszuk, H., 1979. Geneza i ewolucja pokrywy glebowej na wydmach Kotliny Biebrzańskiej. Roczniki Gleboznawcze - Soil Science Annual 30(2), 111-142.

Becher, M., Kalembasa, D., 2006. Charakterystyka bituminów leśnych gleb rdzawych i bielicowych na Nizinie Południowopodlaskiej. Roczniki Gleboznawcze - Soil Science Annual, 57(3/4), 5-12.

Becher, M., Kalembasa, D., 2008. Charakterystyka kwasów huminowych w leśnych glebach rdzawych na Nizinie Południowopodlaskiej. Roczniki Gleboznawcze - Soil Science Annual 59(3/4), 17-22.

Bednarek, R., 1991. Wiek, geneza i stanowisko systematyczne gleb rdzawych w świetle badań paleopedologicznych w okolicach Osia. Rozprawy, UMK Toruń.

Bednarek, R., 2000. Gleby kopalne jako źródło informacji o zmianach środowiska przyrodniczego. Acta Universitatis Nicolai Copernici, Geografia 31, 47-63.

Bednarek, R., Michalska, M., 1998. Wpływ rolniczego użytkowania na morfologię i właściwości gleb rdzawych w okolicach Bachotka na Pojezierzu Brodnickim. Zeszyty Problemowe Postępów Nauk Rolniczych 460, 487-497.

Bednarek, R., Prusinkiewicz, Z., 1980. Geografia gleb. Wydawnictwo Naukowe PWN, Warszawa.

Bednarek, R., Skiba, S., 2015. Czynniki i procesy glebotwórcze [In:] Mocek, A. (Ed.), Gleboznawstwo. Wydawnictwo Naukowe PWN, Warszawa, 68-98.

Białousz, S., 1978; Wpływ morfogenezy Pojezierza Mazurskiego na kształtowanie się gleb. Roczniki Nauk Rolniczych D, 166, 87-154.

Białousz, S., Skłodowski, P., Szafranek, A., 2021. Badania nad kryteriami wyróżniania gleb rdzawych prowadzone w Katedrze Gleboznawstwa Politechniki Warszawskiej. Soil Science Annual 72(4). (in press)

Biały, K., 1997. Problem zniekształcenia i degradacji gleb na przykładzie ekosystemów leśnych w Drawieńskim Parku Narodowym. [In:] Pawlaczyk, P., (Ed.), Gleby i roślinność ekosystemów leśnych w Drawieńskim Parku Narodowym. Sorus, Poznań, 25-42.

Biały, K., 1999. Dowolność wyróżniania typów siedliskowych lasu i projektowania składów docelowych drzewostanów w obrębie gleb bielicoziemnych. Sylwan 143(5), 65-72.

Błońska, E., Lasota, J., Januszek, K., 2013. Variability of enzymatic activity in forest Cambisols and Brunic Arenosols of Polish lowland areas. Soil Science Annual 64(2), 54-59.

Brożek, S., Zwydak, M., 2003. Atlas gleb leśnych Polski. CILP, Warszawa.

Brożek, S., Zwydak, M., Lasota, J., 2008. Liczbowy indeks troficznych odmian podtypów gleb bielicowych i rdzawych. Roczniki Gleboznawcze - Soil Science Annual 59(1), 7-17.

Bryk, M., 2009. Przewodnictwo wodne i wskaźnik jakości leśnej gleby rdzawej. Annales Universitatis Mariae Curie-Skłodowska D, Agricultura 64(4), 9-18.
Chojnicki, J., 2020. Ocena trofizmu gleb Obszaru Ochrony Ścisłej „Rybitew" w Kampinoskim Parku Narodowym na podstawie siedliskowego indeksu glebowego. Sylwan 164(9), 758-766. DOI: https://doi. org/10.26202/sylwan.2020056.

Chojnicki, J., Kwasowski, W., Wójcik, R., 2021. Ocena funkcji i przeznaczenia Glebowej Powierzchni Wzorcowej w Puszczy Białej w zależności od typologii i właściwości gleb. Sylwan 165(3), 223-232. https://doi. org/10.26202/sylwan.2020115.

Chojnicki, J., Kwasowski, W., Zielony, R., 2021. Ocena funkcji i przeznaczenia Glebowej Powierzchni Wzorcowej w Puszczy Białej w zależności od diagnozy siedlisk leśnych. Sylwan 165(4), 296-304. https://doi. org/10.26202/sylwan.2020124.

Chudecka, J., Tomaszewicz, T., 2014. Ocena porolnych gleb rdzawych jako siedliska leśnego na podstawie indeksu trofizmu gleb leśnych (ITGL) i siedliskowego indeksu glebowego (SIG). Zeszyty Naukowe. Inżynieria Środowiska. Uniwersytet Zielonogórski 156(36), 48-57.

Chudecki, Z., Błaszczyk, H., 1980. Zmiany w zawartości połączeń Ca, K, $\mathrm{Na}$ w glebach brunatnoziemnych i rdzawych w zależności od ich użytkowania. Roczniki Gleboznawcze - Soil Science Annual 31(3/4), 227-236.

Czępińska-Kamińska, D., 1986. Zależność między rzeźbą terenu a typami gleb obszarów wydmowych Puszczy Kampinoskiej. SGGW-AR, Warszawa, 5-72.

Czubaszek, R., 2006. Gleby wydm śródtorfowych w Kotlinie Biebrzańskiej i w dolinie Narwi. Zeszyty Naukowe Politechniki Białostockiej. Inżynieria Środowiska 17, 41-62.

Czubaszek, R., Banaszuk, H., 2004. Wybrane właściwości gleb rdzawych na wydmach środtorfowych w bagiennych dolinach Biebrzy i Narwi. Roczniki Gleboznawcze - Soil Science Annual 55(1), 87-98.

Degórski, M., Kowalkowski, A., Kozłowska, A., 2013. Gleby bielicoziemne - geograficzne trendy oraz dyskontynuacje procesów rozwoju. Wydawnictwo Akademickie Sedno, Instytut Geografii i Przestrzennego Zagospodarowania PAN, Warszawa.

Dziadowiec, H., Hentosz, M., Pawlikowski, T., 2002. Wpływ mrówek Formica polyctena (Forster) na właściwości gleb bielicowo-rdzawych w Borach Tucholskich. Roczniki Gleboznawcze - Soil Science Annual 53(1/2), 27-39.

Gus-Stolarczyk, M., Drewnik M., Szymański W., 2021. Origin, properties and transformation of soil lamellae in rusty soils (Brunic Arenosols) in southeastern Poland. Soil Science Annual 74(4), 143881. https://doi. org/10.37501/soilsa/143881 (this issue)

Hirsch, F., Schneider, A., Nicolay, A., Błaszkiewicz, M., Kordowski, J., Noryśkiewicz, A.M., Tyszkowski, S., Raab, A., Raab, T., 2015. Late Quaternary landscape development at the margin of the Pomeranian phase (MIS 2) near Lake Wygonin (Northern Poland). Catena 124, 28-44.

https://www.bdl.lasy.gov.pl/portal/mapy

https://scholar.google.com/scholar?hl=pl\&as_sdt=0\%2C5\&q=gleby+rdzaw e\&btnG $=$

https://www.torun.lasy.gov.pl/pgl-lasy-panstwowe\#.YdGMuWjMLIU

https://yadda.icm.edu.pl/yadda/search/page.action?qt=SEARCH\&q=sc. general*c_0keywords_0eqs.gleby\%2Brdzawe*1_0

IUSS Working Group WRB, 2015. World Reference Base for Soil Resources 2014, update 2015, International soil classification system for naming soils and creating legends for soil maps. World Soil Resources Reports No. 106. FAO, Rome.

Jamroz, E., Weber, J., Dębicka, M., 2014. Wpływ odnowienia lasu zrębem zupełnym na trofizm gleb rdzawych na przykładzie Nadleśnictwa Spała. Sylwan 158(9), 669-674.

Jankowski, M., 2002. Buried soils in the dunes of the Torun Basin. [In:] Manikowska, B., Konecka-Betley, K., Bednarek, R. (Eds.), Paleopedology problems in Poland. Łódzkie Towarzystwo Naukowe, Łódź, 233-252.

Jankowski, M., 2003. Historia rozwoju pokrywy glebowej obszarów wydmowych Kotliny Toruńskiej. PhD thesis, UMK, Toruń 
Jankowski, M., 2013. Gleby ochrowe. Pozycja w krajobrazie, właściwości, geneza i miejsce w systematyce. Wydawnictwo Naukowe UMK, Toruń.

Jankowski, M., 2014. Bielicowanie jako wtórny proces w glebach rdzawych Brodnickiego Parku Krajobrazowego. [In:] Świtoniak, M., Jankowski, M., Bednarek, R. (Eds.), Antropogeniczne przekształcenia pokrywy glebowej Brodnickiego Parku Krajobrazowego. Wydawnictwo Naukowe UMK, Toruń, 9-24.

Jankowski, M., 2018. Charakterystyka uwarunkowań glebowych oraz interpretacja pedostratygrafii stanowiska archeologicznego. [In:] Papiernik, P., Płaza, D.K., (Eds.) Od epoki kamienia do współczesności: badania archeologiczne w Redczu Krukowym na Kujawach. T. 1, Fundacja Badań Archeologicznych im. prof. K. Jażdżewskiego: Muzeum Archeologiczne i Etnograficzne, Łódź, 45-58.

Jankowski, M., 2019. Pokrywa glebowa. [In:] Sewerniak, P., Holc, J. (Eds.), Przyroda poligonu toruńskiego stan badań i problemy ochrony. Wydawnictwo Naukowe UMK, Toruń, 27-42.

Janowska, E., 2001. Geneza i właściwości gleb rdzawych na obszarze zlodowacenia środkowopolskiego. Fundacja Rozwój SGGW, Warszawa.

Jäger, K.D., Kopp, D., 1969. Zur archöologischen Aussage von Profillauschlüssen norddeutscher Sandböden. Ausgrabungen und Funde 14(3), 111-122.

Jonczak, J. 2014. Uwarunkowane litopedogenicznie rozmieszczenie $\mathrm{Cu}$, Ni i Zn w profilach leśnych gleb rdzawych i glejobielicowych terasy nadzalewowej Słupi. Leśne Prace Badawcze 75(4), 333-341.

Jonczak, J., Olejarski, I., Janek, M., 2019. Specjacja fosforu w leśnych glebach rdzawych na obszarach popożarowych. Sylwan 163(5), 396-406.

Jonczak, J., Sztabkowski, K., 2021. Spatial variability of Brunic Arenosols and associated soils along the slope of the Słupia River valley (middle Pomerania, northern Poland). Soil Science Annual 74(4), 143892. https://doi.org/10.37501/soilsa/143892 (this issue)

Kabała, C. et al., 2019. Polish Soil Classification, 6th edition - principles, classification scheme and correlations. Soil Science Annual 70(1), 71-97.

Kabała, C., Ksepko, M., Musiał, P., 2021. Różnorodność typologiczna i fizykochemiczna gleb rdzawych Puszczy Białowieskiej. Soil Science Annual 72(4), 143900. https://doi.org/10.37501/soilsa/143900 (this issue)

Kalembasa, D., Becher, M., 2006. Węgiel i azot w wydzielonych frakcjach materii organicznej leśnych gleb rdzawych i bielicowych Niziny Południowopodlaskiej. Roczniki Gleboznawcze - Soil Science Annual 57(3/4), 44-54.

Klasyfikacja gleb leśnych, 1973. Polskie Towarzystwo Gleboznawcze, V Komisja Genezy, Klasyfikacji i Kartografii Gleb, Zespół Gleb Leśnych, Warszawa.

Klasyfikacja gleb leśnych Polski, 2000. Centrum Informacyjne Lasów Państwowych, Warszawa.

Kobierski, M., Staszak, E., Kondratowicz-Maciejewska, K., Ruszkowska, A., 2011. Wpływ rodzaju użytkowania gleb na zawartość metali ciężkich i ich dystrybucję w profilach gleb rdzawych. Ochrona Środowiska i Zasobów Naturalnych 49, 163-177.

Kondratowicz-Maciejewska, K., Kobierski, M., Murawska, A., 2012. Wpływ rodzaju użytkowania gleb rdzawych na wybrane właściwości fizykochemiczne materii organicznej. Roczniki Gleboznawcze - Soil Science Annual 63(2), 19-24. https://doi.org/10.2478/v10239012-0019-y

Konecka-Betley, K., 1991. Late Vistulain and Holocene fossil soils developed from aeolian and alluvial sediments of the Warsaw Basin. Zeitschrift für Geomorphologie 90, 90-105.

Konecka-Betley, K., Janowska, E., 1996. Wiek i pochodzenie osadów a niektóre procesy glebotwórcze. Roczniki Gleboznawcze - Soil Science Annual 47 (Supl.), 113-123.

Konecka-Betley, K., Janowska, E., 2005. Late glacial and holocene stratotype profile of palaeosols in the Warsaw basin. Studia Quaternaria 22, 3-16.
Konecka-Betley, K., Czępińska-Kamińska, D., Janowska, E., Okołowicz, M., 2002. Gleby stref ochrony ścisłej i częściowej w rezerwacie biosfery „Puszcza Kampinoska”. Roczniki Gleboznawcze - Soil Science Annual 53(3/4), 5-21.

Kowalkowski, A., 1977a. Dynamika rozwoju późnoplejstoceńskich i holoceńskich gleb z piasków wydmowych w Pomorsku. Roczniki Gleboznawcze - Soil Science Annual 28(3/4), 19-35.

Kowalkowski, A., 1977b. Wpływ różnej głębokości wody gruntowej na wilgotność i zasobność gleb rdzawych bielicowanych pod drzewostanami sosnowymi. Roczniki Gleboznawcze - Soil Science Annual 28(3-4), 127-135.

Kowalkowski, A., 1988. Wiek i geneza gleb. [In:] Starkel, L. (Ed.), Przemiany środowiska geograficznego Polski. Ossolineum, Wrocław, 45-85.

Kowalkowski, A., 1994. Peryglacjalne warunki rozwoju gleb na terenach otaczających Stację Geoekologiczną Zintegrowanego Monitoringu Św. Krzyż. [In:] Kowalkowski, A. (Ed.), Zintegrowany Monitoring Środowiska Przyrodniczego, Stacja Bazowa Św. Krzyż. Biblioteka Monitoringu Środowiska. Warszawa, 59-79.

Kowalkowski, A., Borzyszkowski, J., 1974. Research on the reverse couplings between mesorelief and some properties on the FH horizon in a rusty podzolic soil. Roczniki Gleboznawcze - Soil Science Annual 25(sup.), 217-230.

Kowalkowski, A., Degórski, M., 2005. Biogeomorfologiczna odrębność górskich strukturalnych gleb rdzawych bielicowych. Problemy Zagospodarowania Ziem Górskich 52, 7-16.

Kowalkowski, A., Mycielska-Dowgiałło, E., 1980. Soil forming processes in the tundra and arid steppe of the Khangai Mountains on the basis of quartz grain analysis with an electron microscope. Polish Journal of Soil Science 13(1), 59-63.

Kowalkowski, A., Szczęsny P., 1977. Wpływ nawożenia siarczanem amonu na niektóre właściwości chemiczne leśnej gleby rdzawej bielicowanej. Część I. Składniki łatwo rozpuszczalne. Roczniki Gleboznawcze - Soil Science Annual 28(3-4), 73-83.

Kowalkowski, A., Szczęsny, P., 1978. Wpływ nawożenia siarczanem amonu na niektóre właściwości chemiczne leśnej gleby rdzawej bielicowanej. Część II. Właściwości sorpcyjne. Roczniki Gleboznawcze - Soil Science Annual 29(1), 17-25.

Kowalkowski, A., Borzyszkowski, J., Porębska, G., 1981. Geoekologiczne podstawy rozpoznawania i kartografii gleb rdzawych. IBL Warszawa-Sękocin.

Kowalkowski, A., Borzyszkowski, J., Porębska, G., 1985. Wstępne sformułowanie cech diagnostycznych rdzawego poziomu genetycznego w glebach autogenicznych. Sprawozdania z badań naukowych 6, Komitet Badań Czwartorzędu PAN, 71-72.

Kowalkowski, A., Borzyszkowski, J., Szczęsny, P., 1977. Wpływ deszczowania na zawartość łatwo rozpuszczalnych składników mineralnych w leśnej glebie rdzawej bielicowanej. Roczniki Gleboznawcze - Soil Science Annual 28(3-4), 57-71.

Kowalkowski, A., Brogowski, Z., Kocoń, J. 1986. Properties of cryogenic horizons in the profile of rusty soil. Quaternary Studies in Poland 7, 25-37.

Kuźnicki, F., Skłodowski, P., 1974. Zawartość różnych form związków próchnicznych w glebach rdzawych bielicowanych i bielicy wytworzonych z piasków wodnolodowcowych. Roczniki Gleboznawcze - Soil Science Annual 25(sup.), 185-196.

Kuźnicki, F., Białousz, S., Kamińska, H., Oszmańska, M., Rusiecka, D., Skłodowski, P., Ziemińska, A., Żakowska, H., 1978. Typologia gleb wytworzonych z piasków Puszczy Białej w nawiązaniu do rzeźby terenu. Roczniki Nauk Rolniczych D, 166, 57-86.

Lasota, J., Brożek, S., Zwydak, M., Wanic, T., 2011a. Różnorodność gleb acydofilnych lasów liściastych, świetlistej dąbrowy subkontynentalnej oraz ubogich postaci grądów. Roczniki Gleboznawcze - Soil Science Annual 62(4), 73-92. 
Lasota J., Brożek S., Zwydak M., Wanic T., 2011b. Różnorodność gleb żyznych buczyn i grądów. Roczniki Gleboznawcze - Soil Science Annual 62(4), 93-108.

Lasota, J., Zwydak, M., Wanic, T., Brożek, S., 2011c. Różnorodność gleb zespołów borów mieszanych. Roczniki Gleboznawcze - Soil Science Annual 62(4), 54-72.

Lasota, J., Błońska, E., Piaszczyk, W., 2021. State of soil enzymatic activity in relationship to some chemical properties of Brunic Arenosols. Soil Science Annual 72(4), 140641. https://doi.org/10.37501/soilsa/140641 (this issue)

Lemanowicz, J., 2015. Zawartość i dystrybucja fosforu oraz aktywność fosfataz w leśnych glebach rdzawych w obszarze długoletniego oddziaływania Zakładów Azotowych Anwil we Włocławku. Leśne Prace Badawcze 76(3), 250-255.

Maciejewska, A., 1993. Wpływ nawozu organiczno-wapniowo-mineralnego na niektóre właściwości fizykochemiczne gleb rdzawych właściwych wytworzonych z piasków luźnych. Roczniki Gleboznawcze - Soil Science Annual 44(3/4), 113-120.

Magnuski, K., Sienkiewicz, A., Cichocka, I., 2001. Ocena stanu degradacji siedlisk borowych Puszczy Zielonka na podstawie właściwości gleb. Roczniki Akademii Rolniczej w Poznaniu, Leśnictwo 39, 155-164.

Malczyk, P., 1998. Formy żelaza w rdzawych glebach leśnych wytworzonych z piasku wydmowego. Roczniki Gleboznawcze - Soil Science Annual 39(3), 233-235.

Manikowska, B., 1985. O glebach kopalnych, stratygrafii i litologii wydm Polski środkowej. Acta Geographica Lodziensia 52.

Manikowska, B., Bednarek, R., 1994. Fossil preboreal soil on the dune sands in central Poland and its significance for the conception of rusty soils (Cambic Arenosols) genesis. Roczniki Gleboznawcze - Soil Science Annual 44(supl.), 27-39.

Martyn, W., Niemczuk, B., 2009. Wpływ sposobu użytkowania na zawartość i rozmieszczenie różnych form cynku w profilach gleb płowych i rdzawych. Ochrona Środowiska i Zasobów Naturalnych 40, 56-64.

Martyn, W., Niemczuk, B., 2011. Zawartość żelaza i glinu w profilach gleb rdzawych różnie użytkowanych. Ochrona Środowiska i Zasobów Naturalnych 48, 287-296.

Marzec, M., Kabała, C., 2008. Gleby rdzawe i brunatne kwaśne wytworzone ze zwietrzelin granitów w Sudetach - Morfologia, właściwości i systematyka. Roczniki Gleboznawcze - Soil Science Annual 59(3/4), 206-214.

Mycielska-Dowgiałło, E., Woronko, B., 2004. The degree of aeolization of Quaternary deposits in Poland as a tool for stratigraphic interpretation. Sedimentary Geology 168, 149-163.

Niedźwiecki, E., 1984. Zmiany cech morfologicznych i właściwości gleb uprawnych na tle odpowiadających im gleb leśnych na Pomorzu Szczecińskim. Rozprawy AR w Szczecinie 92.

Nowiński, M., 1998. Fluor w glebach rdzawych degradowanych wpływem imisji miejsko-przemysłowych aglomeracji poznańskiej. Roczniki Akademii Rolniczej w Poznaniu, Leśnictwo 36, 89-97.

Nowiński, M., 1999. Siarka w glebach rdzawych degradowanych wpływem imisji miejsko-przemysłowych aglomeracji poznańskiej. Roczniki Akademii Rolniczej w Poznaniu. Leśnictwo 37, 127-137.

Operat, 1999. Operat glebowo-siedliskowy. Nadleśnictwo Gniewkowo. Biuro Usług Techniczno-Leśnych “Butel”, Toruń.

Ostrowska, A., 1977. Akumulacja azotu w glebie rdzawej bielicowanej pod drzewostanem sosnowym nawożonym $\left(\mathrm{NH}_{4}\right)_{2} \mathrm{SO}_{4}$. Roczniki Gleboznawcze - Soil Science Annual 28(3-4), 85-102.

Pokojska, U., Kwiatkowska, A., Szrejder, B., 1995. Przydatność wybranych wskaźników do oceny stopnia zakwaszenia gleb lekkich w zasięgu działania kwaśnych imisji. Zeszyty Problemowe Postępów Nauk Rolniczych 418(1), 383-389.

Pokojska, U., Kwiatkowska, A., Szrejder, B., 1999. Wpływ imisji związków siarki z Toruńskich Zakładów Przemysłu Nieorganicznego Polchem na okoliczne gleby rdzawe. Zeszyty Naukowe Akademii Techniczno-Rolniczej w Bydgoszczy, Rolnictwo 43, 97-106.
Prusinkiewicz, Z., 1969. Gleby wydm śródlądowych w Polsce. [In:] Galon, R. (Ed.), Procesy i formy wydmowe w Polsce. Prace Geograficzne 75, PWN Warszawa, 117-144.

Prusinkiewicz, Z., Bednarek, R., Pokojska, U., 1980. Gleby bielicoziemne w Polsce. Przegląd Geograficzny 52(1), 103-113.

Prusinkiewicz, Z., Bednarek, R., Kośko, A., Szmyt, M., 1998. Paleopedological studies of the age and properties of illuvial bands at an archaeological site. Quaternary International 51-52, 195-201.

Rawling, J.E., 2000. A review of lamellae. Geomorphology 35(1), 1-9.

Rutkowska, P.A., 2019. Przebieg procesu bielicowania w cyklu uprawy monokultur sosnowych w wybranych obszarach piaszczystych Polski Północnej. PhD thesis, UMK, Toruń. (in Polish)

Rutkowski, P., Konatowska, M., Ilek, A., Turczański, K., Nowiński, M., Löffler, J., 2021. Occurrence of rusty soils in forest areas managed by the State Forests National Forest Holding in the light of data from the Forest Data Bank. Soil Science Annual 72(4), 143893. https://doi. org/10.37501/soilsa/143893 (this issue)

Sewerniak, P., Jankowski, M., 2017. Topographically-controlled site conditions drive vegetation pattern on inland dunes in Poland. Acta Oecologica 82, 52-60. https://doi.org/10.1016/j.actao.2017.06.003

Sewerniak, P., Jankowski, M., 2021. Selected problems of sustainable management of rusty soils in forestry. Soil Science Annual 72(4), 143477. https://doi.org/10.37501/soilsa/143477 (this issue)

Sewerniak, P., Puchałka, R., 2020. Topographically induced variation of microclimatic and soil conditions drives ground vegetation diversity in managed Scots pine stands on inland dunes. Agricultural and Forest Meteorology 291, 108054. https://doi.org/10.1016/ j.agrformet.2020.108054

SGP 1, 1956. A Natural and Genetical Classification of Polish Soils (Przyrodniczo-genetyczna klasyfikacja gleb Polski). Roczniki Nauk Rolniczych, 74, seria D, 1-96. (in Polish with English summary)

SGP 2, 1959. Genetical Classification of Polish Soils (Genetyczna klasyfikacja gleb Polski). Roczniki Gleboznawcze - Soil Science Annual 7(2), 1-103. (in Polish with English summary)

SGP 3, 1974. Polish Soil Classification (Systematyka Gleb Polski). Roczniki Gleboznawcze - Soil Science Annual 25(1), 1-148. (in Polish with English summary)

SGP 4, 1989. Polish Soil Classification (Systematyka Gleb Polski). Roczniki Gleboznawcze - Soil Science Annual 40(3/4), 1-150. (in Polish with English summary)

SGP 5, 2011. Polish Soil Classification (Systematyka Gleb Polski). Roczniki Gleboznawcze - Soil Science Annual 62(3), 1-193. (in Polish with English summary)

SGP 6, 2019. Polish Soil Classification (Systematyka Gleb Polski). Soil Science Society of Poland, Commission on Soil Genesis, Classification and Cartography. Wydawnictwo Uniwersytetu Przyrodniczego we Wrocławiu, Polskie Towarzystwo Gleboznawcze, Wrocław - Warszawa: $235 \mathrm{pp}$.

Skiba, S., 1995. Pokrywa glebowa. [In:] Warszyńska, J. (Ed.), Karpaty Polskie, UJ, Kraków, 69-76.

Skiba, S., Drewnik, M., 2003. Mapa gleb obszaru Karpat w granicach Polski. Roczniki Bieszczadzkie 11, 15-20.

Skłodowski, P., 1986. Przemiany materii organicznej w glebach rdzawych i brunatnych kwaśnych. Roczniki Gleboznawcze - Soil Science Annual 37(2-3), 127-137.

Skłodowski, P., Maciejewska, A., 1986. Pierwiastki śladowe w glebach rdzawych wytworzonych z piasków triasowych. Roczniki Gleboznawcze - Soil Science Annual 37(1), 67-78.

Skłodowski, P., Szafranek, A., Bielska A., 2004. Gospodarowanie glebami zaliczanymi do kompleksów 6 i 7 przydatności rolniczej w świetle zrównoważonego rozwoju. [In:] Nawrocki, S., Dobrzański, B., Grundas, S. (Eds.), Bonitacja i klasyfikacja gleb Polski. Wydawnictwo Naukowe FRNA - Instytut Agrofizyki im. Bohdana Dobrzańskiego PAN w Lublinie, 39-41. 
Smal, H., Olszewska, M., 2008. Wpływ zmiany użytkowania ziemi na zawartość Fe w fazie stałej gleby i w roztworze glebowym. Zeszyty Problemowe Postępów Nauk Rolniczych 533, 337-344.

Smólczyński, S., Orzechowski, M., Sięda M., 2021. Diagnosis of the trophism of rusty soils on the basis of soil trophic index in selected coniferous stands in the Rupin forestry in the Kurpie Plain, NE Poland. Soil Science Annual 72(4), 144786. https://doi.org/10.37501/soilsa/144786 (this issue)

Smreczak, B., Jadczyszyn, J., Niedźwiecki, J., 2021. Użytkowanie rolnicze gleb rdzawych w Polsce. Soil Science Annual 72(4), 145586. https:// doi.org/10.37501/soilsa/145586

Soil Survey Staff, 2014. Keys to Soil Taxonomy, 12th ed. USDA-Natural Resources Conservation Service, Washington, DC.

Sommer, M., Halm, D., Geisinger, C., Andruschkewitsch, I., Zarei, M., Stahr, K., 2001. Lateral podzolization in a sandstone catchment. Geoderma 103, 231-247.

Stremme, H., 1939. Die Braunerden. In Blancks Handb. Bodenlehre 3, 160-182.

Sykuła, M., Jankowski, M., Mendyk, Ł., Dąbrowski, M., Jasińska, J., Michalak, J., Michalski, A., Pindral, S., Bednarek, R., 2019. Wczoraj i dziś Mapy gleb Polski 1:300 000 - próba adaptacji do Systematyki gleb Polski 2019 (SGP6). [In:] Bartmiński, P., Dębicki, R., (Eds.), 30. Kongres Polskiego Towarzystwa Gleboznawczego - Gleba źródłem życia. Uniwersytet Marii Curie-Skłodowskiej w Lublinie, Lublin, 108-109.

Szafranek, A., 1989. Wpływ rzeźby terenu i skały macierzystej na kształtowanie się gleby z piaskowców dewońskich i triasowych regionu świętokrzyskiego. Roczniki Gleboznawcze - Soil Science Annual 40(2), 59-81.

Szafranek, A., 1990. Wpływ rzeźby terenu i skały macierzystej na kształtowanie się gleby z piaskowców dewońskich i triasowych regionu świętokrzyskiego. Cz. II. Właściwości chemiczne gleb. Roczniki Gleboznawcze - Soil Science Annual 41(3-4), 157-177.

Szafranek, A., 1992. Wpływ rzeźby terenu i skały macierzystej na kształtowanie się gleby z piaskowców dewońskich i triasowych regionu świętokrzyskiego. Cz. III. Rzeźba terenu. Roczniki Gleboznawcze - Soil Science Annual 43(1/2), 121-131.

Szafranek, A., 1998. Sorpcja fosforanów w glebach rdzawych w relacji do ekstrahowanego glinu i żelaza. Roczniki Gleboznawcze - Soil Science Annual 49(1/2), 61-69.
Szafranek, A., 2000. Właściwości oraz przydatność rolnicza gleb płowych i rdzawych Wysoczyzny Kałuszyńskiej. Szkoła Główna Gospodarstwa Wiejskiego w Warszawie.

Szafranek, A., Skłodowski, P., 1998. Wpływ użytkowania rolniczego na właściwości fizyko-chemiczne gleb rdzawych. Zeszyty Problemowe Postępów Nauk Rolniczych 460, 303-314.

Szafranek, A., Skłodowski, P., 2004. Gospodarka glebami rdzawymi w świetle zrównoważonego rozwoju obszarów wiejskich. Roczniki Gleboznawcze - Soil Science Annual 55(2), 419-425.

Świercz, A., 2005. Zawartość metali ciężkich w glebach rdzawych bielicowych w pobliżu wysypiska odpadów komunalnych w Promniku. Roczniki Gleboznawcze - Soil Science Annual 56(3/4), 106-111.

Świtoniak, M., 2021. Rustification as a collateral process in clay-illuvial soils of northern Poland. Soil Science Annual 72(4), 143444. https:// doi.org/10.37501/soilsa/143444 (this issue)

Wawrzyniak-Gramacka, E., Drab, M., 2007a. Mikroskładniki w leśnych glebach rdzawych Wału Zielonogórskiego. Zeszyty Naukowe. Inżynieria Środowiska. Uniwersytet Zielonogórski 133(13), 439-445.

Wawrzyniak-Gramacka, E., Drab, M., 2007b. Wpływ użytkowania gleb na zawartość fosforu i potasu w glebach rdzawych. Zeszyty Naukowe. Inżynieria Środowiska. Uniwersytet Zielonogórski 133(13), 431-438.

Woronko, B., Pisarska-Jamroży, M., 2016. Micro-Scale Frost Weathering of Sand-Sized Quartz Grains. Permafrost and Periglacial Processes 27(1), 109-122.

Wójcikowska-Kapusta, A., Niemczuk, B., 2010. Effect of Land Use on Lead and Nickel Content and Distribution in Rendzina and Rusty Soil Profiles. Ecological Chemistry and Engineering, A 17(4-5), 519-527.

Uggla, H., Roszko, H., 1974. Wstępne badania gleb rdzawych w borach okolic Szczytna. Sylwan 118(10), 25-35.

Uziak, S., Klimowicz, Z., 2002. Elementy geografii gleb i gleboznawstwa. Wydawnictwo Uniwersytetu Marii Curie-Skłodowskiej, Lublin.

Zeeberg, J., 1998. The European sand belt in eastern Europe - and comparison of Late Glacial dune orientation with GCM simulation results. Boreas 27(2), 127-139.

Zwydak, M., Lasota, J., Brożek, S., Wanic, T., 2011. Różnorodność gleb zespołów borów sosnowych. Roczniki Gleboznawcze - Soil Science Annual 62(4), 39-53.

\section{Słowa kluczowe}

Gleba rdzawa

Gleba roku

Geneza gleb

Klasyfikacja gleb

Geografia gleb
Gleba rdzawa - Gleba Roku 2021 w Polsce. Koncepcje genezy, klasyfikacja i prawidłowości rozmieszczenia geograficznego

\section{Streszczenie}

Gleba rdzawa jest typem gleby wyróżnionym w polskim systemie klasyfikacji gleb, wybranym w Polsce glebą roku 2021. Gleby rdzawe są glebami wykształconymi głównie z osadów piaszczystych różnego pochodzenia (wodnolodowcowego, rzecznego, rzadziej eolicznego i wietrzeniowgo), o sekwencji poziomów A-Bv-C. Jasnopomarańczowy poziom wzbogacania Bv-siderik jest poziomem diagnostycznym tych gleb. Jakość rolnicza gleb rdzawych jest niska, jednak stanowią one cenne siedliska lasów naturalnych oraz gospodarczych, na terenie Polski zajmując ponad $50 \%$ całej powierzchni leśnej. W artykule omówiono ogólne koncepcje genezy gleb rdzawych w następujących aspektach: (1) proces rdzawienia - polegający na tworzeniu się otoczek Fe-Al na ziarnach piasku w poziomie Bv, (2) „suchy pedoklimat” - jako zakładany czynnik odpowiedzialny za brak mobilności tlenków Fe-Al, (3) roślinność lasów iglastych kontra roślinność lasów liściastych jako czynnik glebotwórczy, (4) plejstoceński lub holoceński wiek i ewentualna rola warunków peryglacjalnych. W polskim systemie klasyfikacyjnym gleby rdzawe są aktualnie umiejscowione blisko gleb brunatnych (Cambisols), jednak w przeszłości znajdowały się w jednej jednostce taksonomicznej z glebami bielicowymi. W klasyfikacjach międzynarodowych takie gleby nie są wyróżniane odrębnie i należą do Brunic Arenosols/Psamments. Największe obszary gleb rdzawych w Polsce znajdują się na nizinach i wyżynach, głównie na piaszczystych równinach sandrowych oraz terasach pradolin i dolin. 